\title{
Study on the Situation and Countermeasures for College Patent
}

\author{
Fei Wang ${ }^{1,2, a^{*}}$, Hailan Luo ${ }^{1,2, b}$, Jiangjuo Wang ${ }^{1,2, C}, K^{2}$ angning Dou ${ }^{1, d}$ \\ ${ }^{1}$ Luohe Medical College, Bioengineering Laboratory, Luohe, China \\ ${ }^{2}$ Luohe Key Laboratory of Medical Bioengineering, Luohe, China \\ aWhovering@yahoo.com, bxiaohailuo1224@163.com, cwr0395@sina.com, d779627630@qq.com
}

Keywords: Patent; University; College; Electronic application

\begin{abstract}
Our state encourages innovation-driven development strategy and patent applications as well as conversion are main carriers and contents of innovation. Recently mass entrepreneurship and innovation was carried out by our state leaders. University is the major driving force of innovation. However, there are huge gaps among patents because of different innovative abilities of colleges. Besides, college is an important part of the system of higher education with relatively weak innovative ability and patent application ability. This paper analyzes the causes why colleges lack innovation and patents and puts forward to patent manage system to strengthen the patent consciousness, designate personnel for patent applications, and establish incentive policies.
\end{abstract}

\section{Introduction}

Patent Law of the People's Republic of China was implemented from 1985. There is a qualitative leap for the innovative ability of China along with the changes in terms of economy and technology development in the past decades. In order to be in accordance with the law and develop toward the trend of international intellectual property, the patent law has been modified for several times and has been adhered to international treaty. At present, the innovative ability of China cannot be compared with developed countries such as America and Japan. Yet, innovation-driven development should be important development strategy. Besides, the state has put forward several times to develop the patent ability, narrow the gap with developed countries in front of basically similar conservation standards.

University, as an important part of China's science and technology innovation, has abundant human resources which plays a prominent role in knowledge and technological development. Because of strong support in terms of research funds, universities have strong abilities in terms of basic research and applied research which have obvious society contribution. Therefore, universities have advantages while comparing to enterprises and research institutes. Through the researches on the patent situation as well as countermeasures, we are able to master the application, quality and transformation condition so as to analyze the existing problems and find out solutions. Based on this, we can prefect the university patent protection strategy, improve patent conversion rate and strengthen the combination between universities and industries so as to help them provide better social services.

In recent ten years, the system of university has changed a lot. In general, there are three categories: "211 project" and key universities co-sponsored by province and ministry (211 and key 
universities), ordinary university, college and higher vocational schools (college). There is a huge gap between colleges and another two categories in terms of student cultivation, teacher condition and social recognition. At present, professionals \& technical personnel in college occupies $8.68 \%$ of the total professionals in the system of higher education, which can be regarded as a prior group which needs to be encouraged.

\section{The current patent condition of colleges (Table 1)}

There are large differences of patents in different universities. Research universities such as 211 and key universities have better performance in terms of scientific innovation no matter judge from the perspective of quantity or quality, which are main forces for patent application and authorization. For example, all universities invented 35294 patents in 2013, and the number for 211 and key universities is 24019 (occupying $68.05 \%$ ) which is yet decreased while comparing to $72.4 \%$ in 2004. The possible reason is that the number and scale of universities are expanded. Concerning the professional output (per hundred people), 211 and key universities have 8.36 patents, ordinary university have 2.36 while the number for colleges is only 0.36 which indicate that there is a huge gap of the innovative ability; however, in terms of patent transformation efficiency rate (sold patent/sum of inventions and utility model patent), the selling patent rate for ordinary university is $4.5 \%$ higher than $3.48 \%$ of 211 and key universities and higher than $1.47 \%$ of colleges which indicate that the scientific research of ordinary university is practical and the patents completed by colleges have few recognition.

Patent case varies in different provinces in China, for example, university professional personnel of Henan province is half of Jiangsu and the patent for per one hundred professional personnel is 4.74 much lower than 14.7 of Jiangsu. Besides, the patent transformation efficiency rate of Jiangsu universities is $5.62 \%$ and $3.21 \%$ for Henan, embodying that there is an obvious gap between the central regions and coastal regions in term of education and scientific innovation.

Lack of connections to industries. For a long time, personnel in universities engage in scientific research based on interests or their own development needs, ignoring the innovative motivation from industry needs. Besides, judging from the university conversion rate, it is lower than $5 \%$ which falls far behind $70 \%$ of American and Japanese' patent technology transformation rate, presenting a phenomenon of great investment, great achievement, low transformation and low efficiency. This idle sleeping patent is the main reason for patent inefficiency as well as patent infringement. This also shows that while comparing to developed countries, China's scientific research lacks pushing force for industrial development, the combination between industry and academy is loose. To improve the patent conversion rate, the key lies in the integration of production, academy and research, and the scientific impetus comes from industry practice and research problems come from the production, and aim of research is developing production.

Table 1 Patent Condition of University in 2013[1]

\begin{tabular}{lllllc}
\hline Item & $\begin{array}{l}211 \text { and } \\
\text { key } \\
\text { universities }\end{array}$ & $\begin{array}{l}\text { Ordinary } \\
\text { university }\end{array}$ & $\begin{array}{l}\text { College and } \\
\text { higher vocational } \\
\text { schools }\end{array}$ & Jiangsu & Henan \\
\hline $\begin{array}{l}\text { Invention patent } \\
\text { granted }\end{array}$ & 24019 & 11026 & 249 & 4466 & 631 \\
$\begin{array}{l}\text { Utility Model } \\
\begin{array}{l}\text { Patent } \\
\text { Sold Patents }\end{array}\end{array}$ & 9905 & 14326 & 1587 & 4556 & 772 \\
Professional Staff & 286989 & 467720 & 27 & 507 & 45 \\
\hline
\end{tabular}


High-level talents in colleges and universities have always preferred to work in universities with familiar environment and decent work. Therefore, universities and colleges collect the most innovative force. In recent years, the team continues to grow, making local general universities, and even colleges introduce a dazzling array of doctorate or master's degree talents. In terms of national science and technology funds, university and colleges occupy a half. Yet, in recent two years, the state puts forward the strategy of innovation-driven development, tilting the funds to industrial enterprises and highlight industrial upgrading as important contents to improve national strength, aiming to attract talents to enterprises. What's more, activities in many provinces such as hundred specialists working in hundred enterprises and hundred doctors connecting to enterprises can help to strengthen the cooperation between enterprises and schools.

The patent development in higher vocational school lags behind. There are 345 colleges while most of them are supported by regional capital, occupying $33.30 \%$ of 1036 universities. Besides, there are 74292 professional and technical personnel in colleges, accounting $8.98 \%$ of the total number of university professionals. The school-running objective of colleges and universities is to cultivate talents with academic knowledge as well as skills and techniques which make students have a close relation to then industry. The economic development, funds investment, and introduction of doctors have strengthened scientific platform of colleges. Even though, the scientific condition in colleges cannot compare with other two universities. Yet, if we properly guide the system, scientific research consciousness, innovation consciousness and patent consciousness of professionals in colleges, their scientific research ability will be greatly improved and the backward situation of patent will be changed.

\section{Existing problems and countermeasures for colleges}

Strengthen the scientific research consciousness. Patent is a typical innovative scientific research. However, the innovation consciousness of scientific personnel in colleges is weak. The long-term positioning of colleges development makes university manager have a blurred cognition of scientific research, and they subjectively think that colleges do not have scientific research ability and conditions like 211 and key universities. Therefore, managers in college focus only on their teaching task, look down upon scientific research. At present, a glittering array of schools holds the idea that teaching is an important task and scientific and research work is not essential and is the supplementary of teaching. As a result, there are no enough efforts on cooperation base among industry, academy and research. In addition, they are not aware of the technological condition as well as the real requirement in enterprises and cannot provide powerful technical support for management improvement, product development and technology innovation for enterprises.

Scientific research, as an important way to improve the quality of education, plays an important role in cultivating high-quality professionals, promoting teaching research and constantly innovating teaching methods and contents. Obviously, the scientific research work in higher vocational schools plays an irreplaceable role in overall development. However, under the circumstance that colleges do not have high-level research platform, the practicable program for them is application research to improve production for the regional enterprises. As the connation of development, managers should have a good knowledge of the importance to improve the awareness of scientific research. If the scientific research component in performance review, select superiority was increased research will 
form great diver to facilitate teachers and other professionals to improve service levels and the ability to industries, to provide colleges a powerful force for the long-term development [2].

The innovation consciousness should be strengthened. Innovation is the source for knowledge production, and the necessary connotation of scientific research. Researches without innovation can be regarded as simply followed the herd, original thought and ideas can push the development of science and technology. Innovation needs strength and driving force, while the strength is from continuous knowledge accumulation, the driving force come from the difficult problem of industry product from enterprises cooperated with colleges. In general, the scientific innovation ability of colleges and higher vocational schools is still poor, so as to patents situation. In the future, there should be fierce competition for student in china, and colleges lack innovative ability as well as competence shall be eliminated [3]. The fundamental reason is the lack of incentive mechanism. So we have to make policies, encourage teachers to carry out scientific research, especially those related to industry development so as to improve their innovative ability, strengthen the academic exchange. Furthermore, we should encourage work outside campus to be engaged in work to develop their ability to serve the society.

The patent consciousness should be cultivated. The patent management work of colleges still remains to improve. Most of the patent management work is by the scientific research management department and even some schools don't definite the patent management department, without sophisticated patent reporting and auditing system. As a result, they cannot timely know the production and protection condition of patent in research project process of initiation, development and implementation. In addition, the arbitrary and blind management lead to the condition that a dazzling array of technology does not apply for patent. Furthermore, the scientific and technological achievement transforming channel is not smooth without good safeguard mechanism. Therefore, the transformation and implementation of patent cannot be guaranteed which cannot obtain relevant market benefits. Besides, some authorized patents are given up.

Teachers and other professional personnel in colleges lack patent awareness. As professional technicians in colleges, they still have no normal education background of patent knowledge. This educational background leads to poor patent consciousness, patent idea and patent writing. Besides, concerning the scientific research structure, they highlight paper-publishing and ignore patent application. And professional personnel always ignore the economic value of intellectual property. In order to reach scientific performance requirement, they don't apply for patent but publish papers and apply for project achievement assessment and awards etc. At present, the professional title promoted condition in many provinces includes patent contents, which is pushing them to develop the patent. Yet, the positive effects remain to be seen.

The application channel should be smooth. It becomes more and more convenient to apply for patent. Teachers apply for patent via patent agency institute and one patent invention needs 5000 Yuan and a new practical invention needs about 20 million Yuan in the past time. And this kind of patent application is completed by the agent with rich experiences in patent writing paper. If Professionals in college are trained with patent knowledge, they can independently write the patent. What's more, electronic application is promoted after 2010, and the application fee is accordingly reduced. On average, the registration fee and substantial examination fee is around 1000 Yuan for utility Patent and 500 Yuan for new practical patent. Furthermore, the process is largely shortened, which saves time and money for various technicians and stimulates the enthusiasm for them to apply for patents. 
But management for electronic patent application is a difficult problem in colleges. Inventors of patent applications are independent teachers and students as well as members of the research group. Even though, they have similar technological background, there is always a problem in terms of patent form, logic while carrying out patent writing after the completion of invention which can be corrected by agents before. But universities now promote the use of electronic application, requiring special managers to deal with the electronic application client and emerging issuing. During these professional and complicated works, managers have to complete the writing, uploading, receiving and delivering as well as modification, observations and rectifications. Once the person receives these tasks, he has to take on high risks and responsibilities as much as a paid agent. Colleges lack professional personnel to manage the patent because managers cannot take on various responsibilities at the same time. The work of paid patent agents is transferred to research manager and if there is no incentive mechanism, people are not willing to accept these tasks to manage the client. Therefore, as a patent manager in colleges, his job is more complicated than science projects and awards management. So effective incentive mechanism, such as performance reward for electronic application client manager, need to be carried out to improve electronic patent application rate, make the patent application client flexible and effectively serve the professional technicians [4].

\section{Reference}

[1] Peoples Republic of China Ministry of Education, Science and Technology Division2013 University Scientific Statistics Assembly. Higher Education Press (2013)

[2] X. Ruichao, Combining Industry, Academy and Research to Improve the Research Assessment of Higher Vocational School. Journal of Henan Institute of Engineering (Natural Science Edition) $21(2009) 72-74$

[3] D. Naiquan, L. Zhitao, Q. Xiaofen, Innovation Openness and Collaboration: The Basic Channel for Higher Vocaitonal School-Based on the Quantitative Analysis of SCI and EI in CNKI System. Science and Technology Management Research ,15(2013) 46-51

[4] Y. Weihong, Exploration on the Electronic Application of Colleges and Universities-Take Anhui University of Science and Technology as Example. Anhui Science \& Technology, 1 (2014)38-39 